\title{
Potential Problems and Effective Measures of Network Accounting
}

\section{Information System}

\author{
Xiao Cheng ${ }^{1, a}$ \\ ${ }^{1}$ Nanchang Institute of Technology, Jiujiang, Jiangxi, China, 332000 \\ ${ }^{\mathrm{a}}$ email
}

Keywords: Networking; Accounting Information Systems; Potential Problems; Effective Measures

\begin{abstract}
With the accelerated process of modernization, advanced science and technology has been widely applied. In this context, the Internet-related information systems will get rapid development, such as: accounting information system, the degree of the network has been significantly improved and network accounting information system has been considerable progress. However, there are still some problems which affect the healthy and stable development. This article will network accounting information system analysis to identify potential problems and propose specific measures related, hoping to get the problem resolved.
\end{abstract}

\section{Introduction}

In the present stage of development, accounting information system has become a core component of corporate accounting information technology. Network accounting information system affects the traditional approach of accounting information, accounting information to improve the efficiency of treatment [1]. However, network accounting information system also causes the system to potential problems in the network process, such as: the transmission or storage of information systems are potentially unsafe and not confidentiality. In view of this, the paper network accounting information system of potential problems and effective measures to study significant.

\section{Basic Features of Network Accounting Information System}

Accounting Electronic Payments. Network Accounting Information System for the relevant accounting information is electronically processed transactions in the balance of payments and accounting, but also more by way of electronic payments, this aspect of accounting information systems to achieve the objective requirements of the network, and the other records also conducive to the efficiency of information systems and associated data to enhance the bottom left. Electronic accounting payable perfect adaptation of the network accounting information system and cannot be confined to the limitations of the region, to achieve a seamless connection between the settlement enterprise, thus reducing the cost of payments, largely to facilitate activities related to accounting information.

Paperless Financial Information. Networking is the traditional paper discarded. Network accounting information system relies heavily on networks play-related functions, relying on accounting data entered into the computer data processing accounting data depends on the operation of information systems program. Paperless input can be avoided or inaccurate data related to a clerical error, it is possible to improve the accounting efficiency. 
Pairs of Internal Accounting Control and Higher Requirements. Network accounting information system to achieve the efficient functioning of the accounting information between various departments to be able to achieve a comprehensive information data transmission and retrieval, largely on traditional accounting internal control put forward new requirements [2] . In order to adapt to the normal operation of the network accounting information system, accounting internal control needs facing step manual revision to the program of change control issues, network accounting information system of internal accounting control proposed new requirements.

\section{Advantages of Network Accounting Information System}

Ensure Accurate Data Entry. Enter accounting data, the data needs to be analyzed and categorized, and in strict accordance with the relevant accounting norms for accurate data input fields, the work is complex and larger workload, in the case of a large workload, for complex data input more prone to errors and omissions. In the networked information systems, first for accurate data to distinguish columns, rule-based data input, to have accurate input direction work, so as to effectively prevent erroneous data entry. Secondly, the input data, input competence of each part is divided, the department in charge of the accounting department data entry, work efficiency and professional level has been significantly improved.

Unified and Efficient Accounting Data and Financial Information Processing. Network accounting information system will be centralized and scientific information storage, which can greatly facilitate the whole accounting department can easily access data, real-time financial data to understand and analyze the relevant departments to help business decision-making, raise capital use efficiency, reduce bad debts, leakage accounts, revitalize the stock funds.

Seamless Connection of Accounting Information. Network accounting information system breaks the limitations of traditional accounting information on the geographical and time. To achieve seamless connectivity information on the network, in order to fully meet business managers and accounting departments, and other information at any time demand for accounting information.

Accounting for Cost Control. Network accounting information system, saving cost accounting and accounting acquisition costs. In the context of development of the Internet, financial and accounting information does not need to rely on traditional paper documents, achieved without cost accounting information operation.

\section{Potential Problems of Network Accounting Information System}

Accounting Information System Stability Needs to Be Improved. Network accounting information system does not have sufficient practical use, in large part, a lack of practice. Because the integrity of the accounting information system, in particular accounting data will lead to inaccurate accounting accuracy of the entire information system operation is affected [3]. In addition, the defense needs to improve the accounting information system to improve system security and stability data.

Accuracy of Accounting Information and Confidentiality Insufficient. Play the role of accounting information systems depend primarily on the accuracy and confidentiality of accounting data, when accounting data has been tampered with, accounting systems were attacked, accounting information system will lose the meaning of its existence. In many cases, the accounting information system needs to have a strong ability to withstand external, to ensure the accuracy and confidentiality of data, and the data once the leak, will use the enterprise caused incalculable damage to information systems, the impact of its business activities. 
The System Saves the Transmission Medium Instability. In a networked accounting information system, mainly rely on data storage and transfer to magnetic media. Magnetic media, there are some limitations, mainly reflected in the data has been tampered with and lost. Magnetic media because of its special structure, it is necessary under certain circumstances in order to be fully protected, such as dry conditions, other isolated magnetic object like.

\section{Network Accounting Information System}

To Strengthen the Internal Control System Relevant to Achieve Internal Check. In a networked accounting information system should be implemented for the various functional departments and operating positions clear rights and obligations, specific measures to implement the responsibility to the individual, to achieve the lower layered different operating authority, the right to set the various operating positions, to introduce appropriate containment mechanism to ensure the stability of the internal accounting information system operation.

Establish and Improve the Relevant File Management System. Accounting information system relevant data and financial statements, should implement effective backup of data reporting, timely update the data information. Establish and improve the relevant records management system, strict data archiving operations, the establishment of specialized departments for management and oversight to ensure that no loss of security and confidentiality of data. In addition, the times required, to update the corresponding network knowledge, information and data to achieve stability preservation.

States Should Increase the Control of Accounting Information Network. For some of the threats wrongful network accounting information system, the state should intensify the crackdown, the importance of wrongful discipline in policy, leading public opinion and increase public understanding of crime information network, establish and improve network security management system strengthen the relevant building mechanisms to achieve the constraints related behavior, and promote the development of network security, to provide a stable external environment for networked information systems.

Development and Application of the Relevant Safety Functions. Accounting information data having an important role, accounting for data protection is a network of accounting information systems play a role in an important prerequisite for data protection security features should increase its efforts to step up the pace of research, development and investment related functions use [4]. In this process, it should ensure the normal operation of existing equipment, maintenance of equipment operation and good external environment.

Strengthen Efforts to Train Accounting Personnel. Network accounting information system is an inevitable trend of the times, but also the inevitable requirement of accounting information processing development. In the development of accounting information system should be fully achieve people-centered development philosophy, attention to the cultivation of talents, strengthen personnel training and related skills to master in terms of computerized accounting, and actively introduce advanced accounting information systems, drawing excellent information network the successful experience of the system, can in large part to push the development of network accounting information system.

\section{Conclusion}

Network accounting information system has a lot of advantages, can greatly push the development of the accounting work progress, practice the scientific concept of development and improves work 
efficiency, an effective means to change the traditional extensive mode of operation. In the next stage of development, enterprises and relevant departments should be taken seriously enough level, increase investment, give full play to the initiative, actively engaged in the accounting information system network of building and to give full play to the network accounting information system the role of lay a solid foundation.

\section{REFERENCE:}

[1] Gao Jianying. Fraud and Countermeasures Network Accounting Information System [J]. Chinese Management Information, 2014,22: 31-32.

[2] Ma Yingjuan. The Network Environment for Smes Accounting Information System Reconstruction [J]. Development Research, 2013,01: 153-156.

[3] Fang Zhengsheng. Generating Accounting Information System Development And Its Impact On Future Accounting [J]. Zhengzhou Institute Of Aeronautical Industry Management, 2006, 02: 102-107.

[4] Ma Chunxing. Study under the Network Environment Monitoring Mechanism of Accounting Information System [J]. Accountant, 2012,03: 50-52. 